\title{
KEPUTUSAN PEMBELIAN PERITEL YANG DIPENGARUHI OLEH KUALITAS PRODUK, KESESUAIAN HARGA, DAN KUALITAS PELAYANAN
}

\author{
Oleh: \\ Hery Margono'), Kurniawansyah $\mathbf{M}^{2)}$, Mursida Kusuma Wardani ${ }^{3)}$ \\ herymargono@yahoo.com ${ }^{1)}$, classic.roof@yahoo.co.id $\left.{ }^{2}\right)$, idha_mkw@yahoo.com $\left.{ }^{3}\right)$ \\ Sekolah Tinggi Ilmu Ekonomi IPWI Jakarta1,2,3)
}

\begin{abstract}
ABSTRAK
Penelitian ini bertujuan untuk mengetahui pengaruh kualitas produk, kesesuaian harga, dan kualitas pelayanan terhadap keputusan pembelian peritel di PT. Kurnia Indah Sukses (KIS). Dimana variabel independen yaitu kualitas produk (X1), kesesuian harga (X2), dan kualitas pelayanan (X3) mempengaruhi keputusan pembelian (Y) sebagai variabel dependennya.

Populasi dalam penelitian ini adalah pelanggan. Sampel diambil sebanyak 75 orang responden dengan menggunakan teknik Purposive Sampling. Dengan pendekatan Accidental Sampling, yaitu metode pengambilan sampel yang dilakukan dengan menggunakan siapa saja yang ditemui secara kebetulan sebagai sampel. Analisis data dengan regresi berganda.

Berdasarkan hasil penelitian dilakukan bahwa variabel kualitas produk berpengaruh secara positif terhadap keputusan pembelian. Semakin baik kesesuaian harga akan menaikkan keputusan pembelian. Hasil pengujian pengaruh pelayanan terhadap keputusan pembelian memiliki hubungan positif yang berarti bahwa semakin baik pelayanan akan menaikkan keputusan pembelian. Nilai probabilitas (p) sebesar 0,1 produk memiliki pengaruh dominan terhadap keputusan pembelian di PT. Kurnia Indah Sukses (KIS). Hal ini menunjukkan bahwa alasan utama keputusan konsumen untuk melakukan pembelian di KIS adalah persepsi mereka tentang kualitas produk yang berarti tidak ada pengaruh kualitas pelayanan terhadap keputusan pembelian.
\end{abstract}

Kata Kunci: Kualitas Produk, Kesesuian Harga, Kualitas Pelayanan, Keputusan Pembelian

\section{PENDAHULUAN}

Dalam

rangka dan

kebutuhan

dan

memenuhi keinginannya, konsumen dihadapkan berbagai pilihan produk sehingga terjadi proses pengambilan keputusan pembelian. Pengambilan keputusan pembelian konsumen merupakan suatu proses pemilihan salah satu dari beberapa alternatif penyelesaian masalah yaitu pemenuhan kebutuhan, keinginan maupun harapan konsumen.

Sebelum konsumen memutuskan untuk membeli, biasanya konsumen melalui beberapa tahap terlebih dahulu yaitu mengetahui kebutuhan dan keinginan; pencarian informasi untuk memenuhi kebutuhan dan keinginan; evaluasi alternatif pemenuhan; keputusan membeli atau tidak, perilaku pasca pembelian. Faktor-faktor yang mempengaruhi proses pengambilan keputusan pembelian biasanya terkait dengan lokasi rumah tinggal, jumlah penghasilan per bulan, tingkat pendidikan, jenis pekerjaan, kepribadian, gaya hidup, referensi dari orang lain maupun lainnya.

Proses pengambilan keputusan pembelian konsumen harus memahami sifat-sifat keterlibatan konsumen dengan produk atau jasa. Memahami tingkat keterlibatan konsumen terhadap produk atau jasa berarti pemasar 
berusaha mengidentifikasi hal-hal yang menyebabkan seseorang merasa harus terlibat atau tidak dalam pembelian suatu produk atau jasa. Banyak faktor yang dapat mempengaruhi keputusan pembelian konsumen terhadap suatu produk, seperti kualitas produk, kesesuaian harga, dan kualitas pelayanan.

Kristian dan Widayanti (2016) menyatakan terdapat pengaruh kualitas produk dan harga terhadap keputusan pembelian. Hasil penelitian Gotomo dan Wahyudi (2017) menunjukkan bahwa kualitas produk dan harga berpengaruh terhadap keputusan pembelian di Pochette.

Cahyo (2013) dalam Jurnal Manajemen menyatakan bahwa terdapat pengaruh positif dan signifikan antara kesesuaian harga terhadap keputusan pembelian. Hasil dalam penelitian Adi, dkk (2018) menunjukan bahwa kualitas pelayanan, harga, dan promosi mempunyai pengaruh positif terhadap keputusan pembelian.

\section{TUJUAN PENELITIAN}

Tujuan yang diharapkan dari penelitian ini adalah sebagai berikut:

- Untuk mengetahui apakah terdapat pengaruh kualitas produk terhadap keputusan pembelian peritel dalam pembelian produk di KIS.

- Untuk mengetahui pengaruh kesesuaian harga terhadap keputusan pembelian peritel dalam pembelian produk di KIS.

- Untuk mengetahui pengaruh kualitas pelayanan terhadap keputusan pembelian peritel dalam pembelian produk di KIS.

- Untuk mengetahui pengaruh kualitas produk, kesesuaian harga dan kualitas pelayanan secara bersama-sama terhadap keputusan pembelian peritel dalam pembelian produk di KIS.

\section{TELAAH LITERATUR DAN PENGEMBANGAN HIPOTESIS Kualitas Produk}

Produk menurut Kotler dan Keller (2008) adalah segala sesuatu yang dapat ditawarkan ke suatu pasar untuk memenuhi keinginan dan kebutuhan. Produk yang ditawarkan tersebut meliputi barang fisik, jasa, orang, tempat, organisasi, dan gagasan. Kita dapat mengatakan bahwa penjual telah menghasilkan mutu bila produk atau pelayanan penjual tersebut memenuhi atau melebihi harapan pelanggan (Kotler dan Keller, 2007). Produk yang baik dapat dilihat melalui kualitas produk itu sendiri.

Kualitas produk merupakan fokus utama dalam perusahaan. Untuk produk yang merupakan kebutuhan pokok seperti makanan dan minuman, konsumen sangat mempertimbangkan kualitasnya (Tedjakusuma dkk, 2001). Karena sangat berhubungan dengan kesehatan manusia dan merupakan kebutuhan pokok, maka kualitas produk sangat mempengaruhi pembeli dalam mengambil keputusan pembelian. Apabila kualitas produk ditingkatkan, perilaku konsumen untuk melakukan pembelian juga akan meningkat (Tedjakusuma dkk, 2001).

Menurut Heizer dan Render (2005) kualitas diartikan sebagai faktor yang terdapat dalam suatu barang atau hal yang menyebabkan barang atau hasil tersebut sesuai dengan tujuan untuk apa barang atau hasil itu dimaksudkan dan dibutuhkan. Selanjutnya Heizer dan Render (2005) kualitas diartikan sejumlah dari atribut atau sifat-sifat sebagaimana dideskripsikan dalam produk yang bersangkutan. Konsumen sebagai pengguna produk adalah sebagai penentu atau yang membuat keputusan akhir terhadap mutu produk meskipun produsen memutuskan ketepatan tujuan untuk apa hasil atau produk tersebut dimaksudkan.

Adapun menurut Tjiptono dan Diana (2000) kualitas merupakan suatu kondisi dinamis yang berhubungan dengan produk, jasa, manusia, proses dan lingkungan yang memenuhi atau melebihi harapan. Berdasarkan 
pengertian di atas maka dapat disimpulkan bahwa kualitas merupakan usaha yang dilakukan oleh perusahaan dalam rangka untuk memenuhi atau melebihi harapan pelanggan. Kualitas mencakup produk, jasa, manusia, proses, dan lingkungan. Pada sisi yang lain kualitas juga merupakan kondisi yang selalu berubah (misalnya apa yang dianggap merupakan kualitas saat ini mungkin dianggap kurang berkualitas pada masa yang akan datang).

\section{Kesesuaian Harga}

Harga menurut Kotler dan Amstrong (2006) adalah sejumlah uang yang ditukarkan untuk sebuah produk atau jasa. Untuk itu harga harus sesuai dengan persepsi konsumen tentang produk yang akan ditawarkan. Harga yang tinggi akan mengasumsikan bahwa produk yang ditawarkan memiliki kualitas produk yang tinggi juga. Harga merupakan salah satu faktor penentu konsumen dalam menentukan suatu keputusan pembelian terhadap suatu produk maupun jasa.

Beberapa metode yang dapat digunakan untuk menetapkan harga suatu produk tergantung dari basis yang dipilih oleh perusahaan (Shinta, 2011):

1. Metode penetapan harga berbasis permintaan

Penetapan harga tergantung pada dampak perubahan terhadap permintaan, karena itu perubahan penjualan sebagai akibat perubahan harga perlu diketahui, namun, perubahan harga memiliki oleh seorang manajer.

2. Metode penetapan harga berbasis biaya

Struktur biaya perusahaan (biaya tetap dan biaya variabel) merupakan faktor pokok yang menentukan batas bawah harga.

3. Metode penetapan harga berbasis laba

Ketetapan atas besarnya target laba tahunan yang dinyatakan secara spesifik.

4. Metode penetapan harga berbasis persaingan

Reaksi pesaing terhadap perubahan harga merupakan salah satu faktor penting yang perlu dipertimbangkan setiap perusahaan.

5. Metode penetapan harga berdasarkan geografis

Harga ditetapkan berdasarkan jauh dekatnya lokasi konsumen dengan perusahaan.

6. Metode penentuan harga berdasarkan potongan

Diskon merupakan potongan harga yang diberikan oleh penjual kepada pembeli sebagai penghargaan atas aktivitas tertentu dari pembeli yang menyenangkan bagi penjual.

\section{Kualitas Layanan}

Kualitas layanan adalah setiap kegiatan atau manfaat yang ditawarkan oleh suatu pihak pada pihak lain dan pada dasarnya tidak berwujud, serta tidak menghasilkan kepemilikan sesuatu (Kotler, 2005). Keputusan konsumen dalam membeli dipengaruhi oleh beberapa faktor salah satunya adalah dari segi kualitas layanan yang diberikan oleh perusahaan dan berbagai kemudahan yang diberikan oleh perusahaan terhadap konsumennya baik dari segi fisik maupun nonfisik.

Perusahaan yang bergerak di bidang kuliner, khususnya rumah makan sikap ramah tamah dan sopan dari pramuniaga, serta dilengkapi dengan fasilitas-fasilitas yang baik akan menarik minat konsumen melakukan pembelian.

Salah satu pendekatan kualitas jasa yang banyak dijadikan acuan dalam riset pemasaran adalah model Servqual. Menurut Kotler (2005) dalam model kualitas jasa yang dirumuskan terlihat bahwa pengharapan konsumen dibentuk berdasarkan yaitu:

1. Berwujud (tangible)

Kemampuan suatu perusahaan dalam menunjukkan eksistensinya kepada pihak eksternal. Penampilan dan kemampuan sarana dan prasarana fisik perusahaan yang dapat diandalkan keadaan lingkungan sekitarnya merupakan bukti nyata dari pelayanan yang diberikan, oleh pembeli jasa. Hal ini meliputi fasilitas fisik (contoh: gedung dan gudang), perlengkapan 
dan peralatan yang digunakan (teknologi), serta penampilan pegawainya.

2. Kehandalan (reliability)

Kemampuan perusahaan untuk memberikan pelayanan sesuai dengan yang dijanjikan serta akurat dan terpercaya, kinerja harus sesuai dengan harapan pelanggan yang berarti ketepatan waktu pelayanan yang sama untuk semua pelanggan tanpa kesalahan, sikap yang simpatik, dan dengan akurasi yang tinggi.

3. Daya tanggap (responsiveness)

Suatu kebijakan untuk membantu dan memberikan pelayanan yang cepat (responsif) dan tepat kepada pelanggan, dengan penyampaian informasi yang jelas. Membiarkan konsumen menunggu persepsi yang negatif dalam pelayanan.

4. Jaminan dan kepastian (assurance) Pengetahuan, kesopan-santunan, dan kemampuan para pegawai perusahaan untuk menumbuhkan rasa percaya para pelanggan kepada perusahaan. Hal ini meliputi beberapa komponen antara lain komunikasi, kredibilitas, keamanan, kompetensi, dan sopan santun.

\section{Keputusan Pembelian}

Menurut Kotler dan Keller (2009) keputusan pembelian adalah suatu tahapan proses keputusan pembelian dimana konsumen pada akhirnya membeli suatu produk atas pemenuhan kebutuhan dan keinginan. Proses tersebut merupakan sebuah penyelesain masalah harga yang terdiri dari lima tahap. Lima tahap proses keputusan pembelian tersebut adalah:

1. Pengenalan masalah

Merupakan tahap pertama diproses keputusan pembelian dimana konsumen mengenali masalah atau kebutuhan.

2. Pencarian informasi

Pada tahap ini konsumen digerakkan untuk mencari informasi lebih banyak, konsumen bisa lebih mudah melakukan pencarian informasi aktif, ketika lebih banyak informasi diperoleh maka kesadaran dan pengetahuan konsumen tentang barang atau jasa akan semakin meningkat.

3. Penilaian alternatif

Konsumen menggunakan informasi untuk mengevaluasi merek-merek alternatif dalam himpunan pikiran.

4. Keputusan pembelian

Keputusan seorang konsumen untuk mengubah, menangguhkan, atau membatalkan keputusan membeli, banyak dipengaruhi oleh pandangan risiko seseorang. Besar kecilnya risiko yang ditanggapi seseorang adalah berbeda-beda sesuai dengan besar uang yang dibelanjakan, banyak ciri yang tidak pasti, dan tingkat kepercayaan diri konsumen. Seorang konsumen mengembangkan kebiasaan tertentu untuk mengurangi resiko, seperti membatalkan keputusan, menghimpun informasi dari temanteman, dan memilih sebuah merek nasional dan memiliki jaminan.

\section{Hipotesis}

Hipotesis untuk menjelaskan pengaruh kualitas produk, kesusaian harga, dan kualitas pelayanan terhadap keputusan pembelian pada PT. Kurnia Indah Sukses (KIS) yang diajukan pada penelitian ini adalah:

H1 : Kualitas produk berpengaruh signifikan terhadap keputusan pembelian produk di PT. Kurnia Indah Sukses.

H2 : Kesesuaian harga berpengaruh signifikan terhadap keputusan pembelian produk di PT. Kurnia Indah Sukses.

H3 : Pelayanan berpengaruh signifikan terhadap keputusan pembelian pada PT. Kurnia Indah Sukses.

\section{Kerangka Pemikiran}

Variabel adalah simbol yang nilainya dapat bervariasi, yaitu angkanya dapat berbeda-beda dari satu subjek ke subjek yang lain atau dari satu objek ke objek yang lain. Variasi angka termaksud tidak hanya dalam arti variasi kuantitatif akan tetapi juga dapat mengandung arti variasi kualitatif (Azwar, 2007). Variabel yang digunakan dalam penelitian adalah: 
1. Variabel dependen

Variabel dependen adalah variabel yang menjadi pusat perhatian utama peneliti. Hakikat sebuah masalah mudah terlihat dengan mengenali berbagai variabel dependen yang digunakan dalam sebuah model variabilitas dari atau atas faktor ilmiah yang berusaha untuk dijelaskan oleh seorang peneliti (Ferdinand, 2006). Dalam penelitian ini yang menjadi variabel dependen adalah keputusan pembelian (Y).

2. Variabel independen

Variabel independen yang dilambangkan dengan (X) adalah variabel yang mempengaruhi variabel dependen, baik yang berpengaruh positif maupun negatif (Ferdinand, 2006). Variabel independen dalam penelitian ini adalah variabel kualitas produk (X1), variabel kesesuaian harga (X2), dan variabel kualitas pelayanan (X3).

Gambar 1

Kerangka/Konstelasi

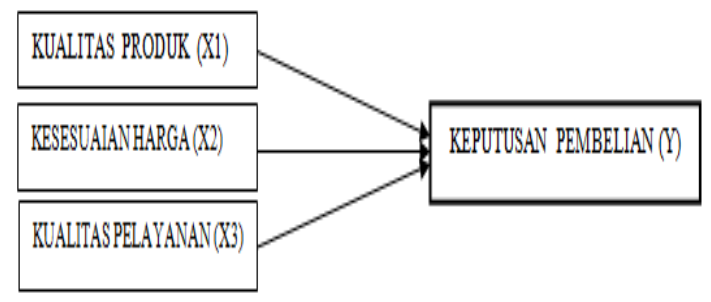

\section{METODE PENELITIAN}

Penelitian ini dilakukan di PT. Kurnia Indah Sukses pada bulan Desember 2017. Dalam penelitian ini penulis menggunakan pendekatan penelitian kuantitatif yaitu metode penelitian ilmiah untuk mendapatkan data yang valid dengan tujuan dapat membuktikan dan mengembangkan suatu pengetahuan. Metode penelitian kuantitatif merupakan bentuk penelitian yang ditujukan pada pemecahan masalah yang dianalisis secara statistik dalam rangka menguji kebenaran hipotesis yang diajukan.

Jenis penelitian yang digunakan dalam penelitian ini adalah explanatory research (penelitian penjelasan) dengan pendekatan kuantitatif. Dalam penelitian ini yang menjadi variabel dependen adalah keputusan pembelian (Y) sedangkan variabel independen dalam penelitian ini adalah variabel kualitas produk (X1), variabel kesesuaian harga (X2), dan variabel kualitas pelayanan (X3). Sampel yang diambil dalam penelitian ditetapkan sebanyak 75 orang pelanggan KIS. Teknik pengambilan sampel dalam penelitian ini dilakukan dengan teknik Accidental Sampling. Data dikumpulkan menggunakan kuesioner yang kemudian dianalisa dengan analisis deskriptif dan analisa regresi berganda.

\section{HASIL DAN PEMBAHASAN Hasil Penelitian}

Analisis ini digunakan untuk mengetahui besarnya pengaruh variabelvariabel bebas independen (kualitas produk, kesesuaian harga, dan kualitas pelayanan) dengan variabel dependen (keputusan pembelian) KIS. Dari pengolahan data statistik maka diperoleh persamaan regresi sederhana dan linear berganda sebagai berikut:

$$
\begin{aligned}
\mathrm{Y}= & 7,264+0,470 \mathrm{X} 1 \ldots \ldots \ldots \ldots \ldots . .(\mathrm{i}) \\
\mathrm{Y}= & 5,688+0,515 \times 2 \ldots \ldots \ldots \ldots \ldots \ldots \text { (ii) } \\
\mathrm{Y}= & 12,709+0,914 \mathrm{X3} \ldots \ldots \ldots \ldots \ldots \text { (iii) } \\
\mathrm{Y}= & -0.321+0.371 \mathrm{X} 1+0.364 \mathrm{X} 2+ \\
& 0,119 \text { X3 .........(iv) }
\end{aligned}
$$

Dengan mengggunakan metode analisis regresi sederhana menunjukkan bahwa kualitas produk (X1) menghasilkan $\mathrm{t}$ hitung sebesar 4,077 > t tabel yaitu 1,993 dengan nilai $\mathrm{b}$ sebesar 0,470 dan nilai signifikansinya sebesar $0,000<a=0,05$; kesesuaian harga (X2) menghasilkan t hitung sebesar 4,637 >t tabel yaitu 1,993 dengan nilai b sebesar 0,515 dan nilai signifikansinya sebesar $0,000<\mathrm{a}=0,05 ;$ dan kualitas pelayanan (X3) menghasilkan $t$ hitung sebesar $2,073>\mathrm{t}$ tabel yaitu 1,993 dengan nilai $\mathrm{b}$ sebesar 0,914 dan nilai signifikansinya sebesar $0,042<\mathrm{a}=$ 0,05 . Variabel $\mathrm{X} 1, \mathrm{X} 2$, dan $\mathrm{X} 3$ masingmasing memiliki pengaruh positif dan signifikan terhadap keputusan membeli.

Apabila menggunakan metode analisis regresi berganda menghasilkan 
konstanta (a) $=0,321$ menyatakan bahwa jika ketiga variabel bebas dianggap konstan maka keputusan pembelian $(\mathrm{Y})$ nilainya 0,321 . Koefisien regresi $(b 1)=0,371$ menyatakan bahwa setiap penambahan nilai 1 satuan dari variabel kualitas produk akan meningkatkan nilai keputusan pembelian sebesar 0,371 dengan anggapan bahwa nilai alphanya konstan atau tetap.

Koefisien regresi $(\mathrm{b} 2)=0,364$ menyatakan bahwa setiap penambahan nilai 1 satuan dari variabel kesesuian harga akan meningkatkan nilai keputusan pembelian sebesar 0,364 dengan anggapan bahwa nilai alphanya konstan atau tetap. Koefisien regresi (b3) $=0,119$ menyatakan bahwa setiap penambahan nilai 1 satuan dari variabel kualitas pelayanan akan meningkatkan nilai keputusan pembelian sebesar 0,119 dengan anggapan bahwa nilai alphanya konstan atau tetap.

Berdasarkan analisis data statistik, indikator-indikator pada penelitian ini bersifat valid dan variabelnya bersifat reliabel. Pada pengujian asumsi klasik, model regresi bebas multikolonieritas, tidak terjadi heteroskedastisitas, dan berdistribusi normal. Urutan secara individu dari masing-masing variabel yang paling berpengaruh adalah variabel kualitas produk lalu kualitas pelayanan, sedangkan variabel yang berpengaruh paling rendah adalah harga.

Berdasarkan uji $\mathrm{F}$, pada $\mathrm{F}$ hitung dengan tingkat signifikasi 0,000 jauh lebih kecil dari level significant yang digunakan yakni $\mathrm{a}=0,05(5 \%)$ dan diketahui nilai $\mathrm{F}$ hitung $15,726>\mathrm{F}$ tabel 2,68 maka tolak Ho dan terima Ha yang berarti bahwa ada pengaruh signifikan secara simultan antara variabel independen terhadap variabel dependen. Sehingga hipotesis yang berbunyi ada pengaruh positif secara bersama-sama terbukti kualitas produk, pelayanan, dan kesesuaian harga terhadap keputusan pembelian di PT. Kurnia Indah Sukses.

Adjusted R square sebesar 0,698. Hal ini berarti $69,8 \%$ variabel dependen keputusan pembelian (Y) dapat dijelaskan oleh variabel-variabel independen yaitu variabel produk, harga, dan kualitas layanan. Sedangkan sisanya $(100 \%-69,8 \%=30,2 \%)$ dijelaskan oleh variabel-variabel lain yaitu lingkungan, sosial budaya yang meliputi keluarga, sumber informasi, sumber non komersil, kelas sosial, sub budaya dan budaya (Schiffman dan Kanuk, 2007).

\section{Hipotesis 1 (H1) Pengaruh Kualitas Produk terhadap Keputusan Pembelian}

Pengaruh secara parsial antara harga terhadap keputusan pembelian sebesar 4,189 dengan nilai b sebesar 0,371 dan sign. $0,000<a=0,05$. Akibatnya Ho ditolak dan Ha diterima. Kualitas produk berpengaruh signifikan terhadap keputusan pembelian, maka dapat disimpulkan bahwa hipotesis (Ha) yang berbunyi "kualitas produk berpengaruh signifikan terhadap keputusan pembelian produk di PT. Kurnia Indah Sukses" diterima, maka dengan demikian hipotesis pertama (H1) diterima.

\section{Hipotesis 2 (H2) Pengaruh Kesesuaian Harga terhadap Keputusan Pembelian \\ Pengaruh kesesuaian harga} terhadap keputusan pembelian secara parsial antara harga terhadap keputusan pembelian sebesar 3,467 dengan nilai $\mathrm{b}$ sebesar 0,364 dan sign. $0,001<a=0,05$. Akibatnya Ho ditolak dan $\mathrm{Ha}$ diterima. Kesesuian harga berpengaruh signifikan terhadap keputusan pembelian, maka dapat disimpulkan bahwa hipotesis (Ha) yang berbunyi "kesesuaian harga berpengaruh signifikan terhadap keputusan pembelian produk di PT. Kurnia Indah Sukses" diterima, maka dengan demikian hipotesis kedua (H2) diterima.

\section{Hipotesis 3 (H3) Pengaruh Kualitas Pelayanan terhadap Keputusan Pembelian}

Pengaruh secara parsial antara kualitas pelayanan terhadap keputusan pembelian sebesar 1,546 dan nilai $b$ sebesar 0,119 dengan sign. 0,127 >a= 
0,05. Maka Ha ditolak dan Ho diterima. Jadi dapat disimpulkan harga berpengaruh positif tapi tidak signifikan terhadap keputusan pembelian, artinya harga tidak berpengaruh terhadap keputusan pembelian maka dapat disimpulkan bahwa hipotesis (Ha) yang berbunyi "pelayanan berpengaruh signifikan terhadap keputusan pembelian pada PT. Kurnia Indah Sukses" ditolak, maka dengan demikian hipotesis ketiga (H3) ditolak.

\section{Pembahasan \\ Pengaruh Kualitas Produk terhadap Keputusan Pembelian}

Produk yang berkualitas dapat mempengaruhi keputusan pembelian. Hal ini sejalan dengan penelitian yang dilakukan oleh Munfarida (2007) dengan judul Pengaruh Harga, Kualitas Produk terhadap Keputusan Pembelian (Studi Kasus Produk Kosmetik Pond's di Ratu Swalayan) yang menyatakan bahwa variabel kualitas produk mempunyai pengaruh yang paling dominan terhadap keputusan pembelian.

Penelitian ini juga didukung oleh penelitian Arumsari dan Khasanah (2012). Hasil penelitian tersebut menunjukkan bahwa variabel kualitas produk berpengaruh positif dan signifikan terhadap keputusan pembelian dalam penelitian yang berjudul Analisis Pengaruh Kualitas Produk, Harga, dan Promosi terhadap Keputusan Pembelian Air Minum dalam Kemasan (AMDK) Merek Aqua (Studi pada Konsumen Toko Bhakti Mart KPRI Bhakti Praja Provinsi Jawa Tengah).

\section{Pengaruh Kesesuaian Harga terhadap Keputusan Pembelian}

Kesesuian harga berpengaruh terhadap keputusan pembelian. Hasil penelitian ini didukung oleh Baedowi dan Lataruva (2012), yang menyatakan bahwa kesesuaian harga adalah faktor paling penting yang mempengaruhi keputusan pembelian konsumen dalam penelitiannya yang berjudul Analisis Pengaruh Kualitas Produk, Kesesuaian Harga, dan Intensitas Promosi terhadap Keputusan Pembelian Konsumen pada Merek Rokok Djarum Super (Studi
Kasus pada Konsumen Rokok Djarum Super di Kota Semarang).

\section{Pengaruh Kualitas Pelayanan terhadap Keputusan Pembelian}

Sehingga dapat disimpulkan bahwa tidak terdapat hubungan antara kualitas pelayanan dengan keputusan pembelian produk di PT. Kurnia Indah Sukses. Seperti diketahui bahwa pelayanan harus sesuai dengan persepsi konsumen tentang produk yang akan ditawarkan. Maka aspek pelayanan tidak mempengaruhi keputusan pembelian karena produk yang mereka dapatkan telah sesuai dengan keinginan jadi pelayanan tidak menjadi dalam penentuan keputusan pembelian.

$\mathrm{Hal}$ ini bertentangan dengan penelitian yang dilakukan oleh Kurniasari dan Santosa (2013), dalam penelitiannya yang berjudul Analisis Pengaruh Harga, Kualitas Produk, dan Kualitas Pelayanan terhadap Keputusan Pembelian (Studi Kasus pada Konsumen Waroeng Steak \& Shake Cabang Jl. Sriwijaya 11 Semarang), yang menyatakan bahwa hasil penelitian menunjukkan bahwa harga, kualitas produk, dan kualitas pelayanan memiliki pengaruh yang positif dan signifikan terhadap keputusan pembelian.

\section{KESIMPULAN \\ Simpulan}

- Hasil analisis menunjukkan bahwa variabel kualitas produk berpengaruh secara positif terhadap keputusan pembelian. Kualitas produk berpengaruh paling dominan dibandingkan variabel kesesuaian harga dan kualitas pelayanan. Hal ini berarti bahwa semakin baik kualitas produk yang ditawarkan PT. Kurnia Indah Sukses maka semakin tinggi pula minat konsumen untuk melakukan pembelian.

- Hasil analisis menunjukkan bahwa kesesuaian harga berpengaruh positif terhadap keputusan pembelian. Artinya harga produk PT. Kurnia Indah Sukses sudah 
sesuai dengan persepsi konsumen yang diharapkan seperti, harganya lebih murah, gratis biaya pengiriman dan harga sudah sesuai dengan harga pasar, dan sistem pembayarannya juga sudah fleksibel. Hal ini berarti bahwa kesesuaian harga mempengaruhi seseorang dalam melakukan pembelian produk di PT. Kurnia Indah Sukses dimana semakin tinggi kesesuaian harga maka minat pembeli akan semakin tinggi.

Hasil analisis menunjukkan bahwa kualitas pelayanan merupakan salah satu faktor yang tidak mempengaruhi konsumen untuk melakukan pembelian produk di PT. Kurnia Indah Sukses dikarenakan kualitas pelayanan relatif sama dengan perusahaan lainnya. Variabel pelayanan diharapkan adanya perubahan karena faktor pelayanan belum menjadi variabel atau faktor dalam mengambil keputusan dalam pembelian di PT. Kurnia Indah Sukses. Pelayanan perlu mendapatkan perhatian dari perusahaan agar dapat mempertahankan pelanggan serta memperoleh pelanggan yang baru. Jika ada peningkatan pelayanan ke pelanggan maka hal ini memberikan implikasi bahwa seorang konsumen akan merasa terpuaskan jika harapan mereka terpenuhi.

\section{Saran}

Mengingat persaingan dalam bisnis semakin ketat, PT. Kurnia Indah Sukses hendaknya meningkatkan kualitas produk dengan melakukan inovasi terus menerus serta memenuhi kebutuhan, keinginan dan harapan konsumen yang selalu berubah. Untuk meningkatkan keputusan pembelian, disarankan kegiatan yang berupa pemberian jaminan (garansi) produk lebih panjang dari yang sekarang 3 bulan, dan garansi harus tetap dilakukan terus agar minat konsumen semakin tinggi dan tertarik untuk membeli.
- Dalam rangka menetapkan harga hendaknya memperhatikan harga pesaing dan sesuai dengan kualitasnya. Selain itu perusahaan hendaknya selalu mencari pemasok (supplier) agar mendapatkan harga jual yang murah ke konsumen.

$\begin{array}{lrr}\text { Kualitas pelayanan } & \text { perlu } \\ \text { mendapatkan perhatian dari } & \text { dapat } \\ \text { perusahaan agar } & \text { dang } \\ \text { meningkatkan daya saing dan } \\ \text { mengembangkan }\end{array}$
dalam menguasai pangsa pasar terutama mampu melayani konsumen dengan cepat sesuai dengan janji dan perlu pelatihan karyawan agar pelayanan lebih cepat dan sigap, khususnya dalam penanganan keinginan dan keluhan konsumen, dengan siap dan memberikan informasi yang tepat kepada pelanggan agar konsumen merasa pelayanan PT. Kurnia Indah Sukses bagus.

\section{DAFTAR PUSTAKA}

Adi, Daniel Okki Rizki Kesuma, dkk. 2018. Pengaruh Kualitas Pelayanan, Harga, dan Promosi terhadap Keputusan Pembelian Produk CKE Teknik Semarang. Journal of Management, Vol. 4 No. 4.

Arumsari, Dheany dan Imroatul Khasanah. 2012. Analisis Pengaruh Kualitas Produk, Harga, dan Promosi terhadap Keputusan Pembelian Air Minum dalam Kemasan (AMDK) Merek Aqua (Studi pada Konsumen Toko Bhakti Mart KPRI Bhakti Praja Provinsi Jawa Tengah). Semarang: Universitas Diponegoro.

Azwar, Syaifuddin. 2007. Sikap Manusia Teori dan Pengukurannya. Edisi 2. Yogyakarta: Pustaka Pelajar.

Baedowi ZA, Mohammad Maftuh dan Eisha Lataruva. Analisis Pengaruh Kualitas Produk, Kesesuaian Harga, dan Intensitas Promosi terhadap Keputusan Pembelian Konsumen pada Merek Rokok Djarum Super (Studi Kasus pada Konsumen Rokok Djarum Super di 
Kota Semarang). Diponegoro Journal of Management, Vol. 1 No. 4: 254-261.

Cahyo, Ahcmad Nur. 2013. Analisis Pengaruh Kualitas Produk Kesesuaian Harga, dan Promosi terhadap Keputusan Pembelian Laptop Maupun PC Lenovo (Studi pada CV Yestoya Abadi). Jurnal Penelitian Manajemen.

Gotomo, Edward dan Alexander Wahyudi. 2017. Pengaruh Kualitas Produk dan Harga terhadap Keputusan Pembelian di Pochette. Jurnal Performa, Vol. 2 No. 2: 221227.

Ferdinand, Augusty. 2006. Metode Penelitian Manajemen. Semarang: Badan Penerbit Universitas Diponegoro.

Heizer, Jay dan Barry Render. 2005. Operation Mangement. 7th ed. New Jersey: Prentice Hall.

Kotler, Philip. 2005. Manajemen Pemasaran. Jakarta: PT. Indeks Kelompok Gramedia.

Kotler, P dan Gary Amstrong. 2006. Principles of Marketing. Eleventh Edition. New Jersey: Pearson Prentice Hall.

Kotler, P dan K. L. Keller. 2007. Manajemen Pemasaran. Edisi Dua Belas. Jakarta: PT. Indeks Kelompok Gramedia. 2008. Manajemen Pemasaran. Edisi Tiga Belas Jilid 1. Jakarta: PT. Gelora Aksara Pratama. 2009. Manajemen Pemasaran, Edisi 13 Jilid 2. Jakarta: PT. Indeks Kelompok Gramedia.

Kristian, Denny dan Rita Widayanti. 2016. Pengaruh Kualitas Produk dan Harga terhadap Keputusan Pembelian Sepeda Motor Honda pada Mahasiswa Kampus I Universitas Kristen Krida Wacana. Jurnal Imiah Manajemen Bisnis, Vol. 16 No. 1: 45-58.

Kurniasari, Nova Dhita dan Suryono Budi Santosa. 2013. Analisis Pengaruh Harga, Kualitas Produk, dan Kualitas Pelayanan terhadap Keputusan Pembelian (Studi Kasus pada Konsumen Waroeng Steak \& Shake Cabang Jl. Sriwijaya 11
Semarang). Diponegoro Journal of Management, Vol. 2 No. 2: 352363.

Munfarida, Rina Shoimatul. 2007. Pengaruh Harga, Kualitas Produk terhadap Keputusan Pembelian (Studi Kasus Produk Kosmetik Pond's di Ratu Swalayan). Skripsi. Malang: Universitas Islam Negeri Maulana Malik Ibrahim.

Shinta, A. 2011. Manajemen Pemasaran. Malang: Penerbit Universitas Brawijaya Press.

Schiffman, L.G dan Leslie L. Kanuk. 2007. Consumer Behavior. New Jersey: Pearson Prestice Hall.

Tedjakusuma, Ritawati, dkk. Analisis Faktor-faktor yang Mempengaruhi Perilaku Konsumen dalam Pembelian Air Minum Mineral di Kotamadya Surabaya. Jurnal Penelitian Dinamika Social, Vol. 1 No. 3: 47-58.

Tjiptono, Fandy dan Anastasia Diana. 2000. Total Quality Mangement. Edisi Revisi. Yogyakarta: Andi Offset. 
